ISSN 1996-1944

www.mdpi.com/journal/materials

Article

\title{
Life Cycle Assessment for Proton Conducting Ceramics Synthesized by the Sol-Gel Process
}

\section{Soo-Sun Lee and Tae-Whan Hong *}

Department of Materials Science and Engineering/Research Center of Sustainable Eco-Devices and Materials (ReSEM), Korea National University of Transportation, Daehak-ro 50, Chungju, Chungbuk 380-702, Korea; E-Mail: tjgona@ut.ac.kr

* Author to whom correspondence should be addressed; E-Mail: twhong@ut.ac.kr; Tel.: +82-43-841-5388; Fax: +82-43-841-5380.

Received: 12 June 2014; in revised form: 3 September 2014 / Accepted: 8 September 2014 / Published: 16 September 2014

\begin{abstract}
In this report, the environmental aspects of producing proton conducting ceramics are investigated by means of the environmental Life Cycle Assessment (LCA) method. The proton conducting ceramics $\mathrm{BaZr}_{0.8} \mathrm{Y}_{0.2} \mathrm{O}_{3-\delta}(\mathrm{BZY}), \mathrm{BaCe}_{0.9} \mathrm{Y}_{0.1} \mathrm{O}_{2.95}$ (BCY10), and $\mathrm{Sr}\left(\mathrm{Ce}_{0.9} \mathrm{Zr}_{0.1}\right)_{0.95} \mathrm{Yb}_{0.05} \mathrm{O}_{3-\delta}(\mathrm{SCZY})$ were prepared by the sol-gel process. Their material requirements and environmental emissions were inventoried, and their energy requirements were determined, based on actual production data. This latter point makes the present LCA especially worthy of attention as a preliminary indication of future environmental impact. The analysis was performed according to the recommendations of ISO norms 14040 and obtained using the Gabi 6 software. The performance of the analyzed samples was also compared with each other. The LCA results for these proton conducting ceramics production processes indicated that the marine aquatic ecotoxicity potential (MAETP) made up the largest part, followed by fresh-water aquatic ecotoxicity potential (FAETP) and Human Toxicity Potential (HTP). The largest contribution was from energy consumption during annealing and calcinations steps.
\end{abstract}

Keywords: life cycle assessment; BZY20; BCY10; SCZY; sol-gel 


\section{Introduction}

A large number of proton conducting ceramics based on $\mathrm{SrCeO}_{3}, \mathrm{BaCeO}_{3}$ have been developed for many applications [1]. These peroveskite-type oxides are used as solid membranes, in hydrogen sensors and as electrode materials for fuel cells [2], because of their appreciable proton and electronic conductivities [3].

The most widely used synthesissynthetic techniques for these materials have been solid state reaction and sol-gel methods. Solid state processes require high temperature and small particle sizes and have difficulty producing homogeneous composites. In contrast, the sol-gel method can produce high purity materials with good homogeneity at low temperatures [4], but it can be expensive relative to the solid-state reaction approach.

In assessing the sol-gel method for proton conducting ceramics, it is important to consider the technology, economic cost, and environmental impacts. However, to data few studies have made a life cycle assessment of the sol-gel process.

Life Cycle Assessment (LCA) is a technique which can be usefully integrated with technical and, economic assessments of processes. The main aim of LCA is to calculate the environmental impacts of products or processes over their full life-cycle. Such results enable a fair comparison between products or processes and can also contribute to designing products which have a minimal environmental impact. Issues involving toxic emissions or waste can be solved by replacing materials or processes, as can issues impacts related to raw materials and consumed energy.

To synthesize doped perovskites such as BZY20 $\left(\mathrm{BaZr}_{0.8} \mathrm{Y}_{0.2} \mathrm{O}_{3-\delta}\right)$, BCY10 $\left(\mathrm{BaCe}_{0.9} \mathrm{Y}_{0.1} \mathrm{O}_{2.95}\right)$, and SCZY $\left(\operatorname{Sr}\left(\mathrm{Ce}_{1-\mathrm{x}} \mathrm{Zr}_{\mathrm{x}}\right)_{0.95} \mathrm{Yb}_{0.05} \mathrm{O}_{3-\delta}\right)$, rare earth metal are used [5-7], including for example, cerium and yttrium . Because the demand for rare earth metals for many application is high in proportion to their small worldwide deposits resource depletion should also be considered when assessing environmental impact.

Thus, this paper aims to present the main results of an LCA applied to the synthesis of proton conducting ceramics (BZY20, BCY10, SCZY) by the sol-gel method, focusing on the main environmental problems of ceramic production, and the opportunities for improvement derived from this analysis. The presented LCA study was performed with the ISO 14040 series.

\section{Life Cycle Impact Assessment (LCIA)}

The LCA is an ISO standardized method (ISO 14040-14044). The quality of an LCA depends on having an accurate description of the production process to be analyzed. It is necessary to collect and interpret that process data to learn where each stage of a life cycle properly begins and ends. In this study, to determine the environmental performance of the processes being studied, a combined Life Cycle Impact Assessment method developed at the University of Leiden, the so called CML (Centrum voor Milieuweten schappen (Institute of Environmental Sciences)) method was used. The CML method defines several impact categories for emissions and for resource consumption as problem-oriented (mid-points) [8]. This method then groups the by-products, emissions and resource consumption caused by the targeted processes into specific environmental impacts, such as global warming potential, acidification potential, ozone depletion potential, etc. And these categories are 
expressed using the reference unit like as $\mathrm{kg} \mathrm{CO}_{2}, \mathrm{SO}_{2}$ equivalent. In addition, normalization is applied to compare midpoint impacts.

\subsection{Goal and Scope}

The goal of conducting an environmental impact assessment of the sol-gel process of BZY20, BCY10, and SCZY is to get a clear understanding of which different materials and process steps have the potential to cause most of the environmental burdens. The assessment can also evaluates potential damage to human health. The analysis results will then be used to suggest how to lower the overall environmental impact of the Sol-gel process. This study is a 'gate-to-gate' assessment. The system boundaries are the synthesis of the BZY20, BCY10, SCZY powder including the sol-gel process of raw materials and heat treatment, except for the raw material stage and the transport step

Figure 1 shows a description of the system and each phase. Data was collected from two stages, sol-gel and heat treatment. The function is defined as a material for the hydrogen membrane, hydrogen gas sensor, hydrogen extractor and fuel cells. Thus, the functional unit of the system was $1 \mathrm{~g}$ of powder for each material. All raw materials, wastes, and emissions are based on this functional unit. The electricity considered a power production relies on fossil fuels, price assumed to be from mixed power sources in the Netherlands.

\subsection{Inventory Analysis}

Inventory data for the synthesis of the proton conducting ceramics are presented in Table 1. The inventory data were collected from the literature [5-7] and from laboratory experiment, and Ecoinvent Database v2.2 (Swiss Centre for Life Cycle Inventories, Technoparkstrasse, Zürich, Switzerland, 2010) was used [9]. For investigation of the production of proton conducting ceramics, the software Gabi 6 was used. Gabi is a life cycle analysis program and its database contains ecoinvent data for energy, material, and transport systems. Moreover, it can evaluate life cycle environmental, cost, and social profiles of products, processes, and technologies [10].

Table 1. Life cycle inventory for the synthesis of BZY20 $\left(\mathrm{BaZr}_{0.8} \mathrm{Y}_{0.2} \mathrm{O}_{3-\delta}\right), \mathrm{BCY} 10$ $\left(\mathrm{BaCe}_{0.9} \mathrm{Y}_{0.1} \mathrm{O}_{2.95}\right)$ and SCZY $\left(\mathrm{Sr}\left(\mathrm{Ce}_{1-\mathrm{x}} \mathrm{Zr}_{\mathrm{x}}\right)_{0.95} \mathrm{Yb}_{0.05} \mathrm{O}_{3-\delta}\right)$.

\begin{tabular}{cccc}
\hline Classification & BZY20 & BCY10 & SCZY \\
\hline & Ammonia $(3.6 \mathrm{~g})$ & Barium $(0.6 \mathrm{~g})$ & Ammonia $(0.6 \mathrm{~g})$ \\
& Barium $(1.3 \mathrm{~g})$ & Cerium $(1.0 \mathrm{~g})$ & Cerium $(1.9 \mathrm{~g})$ \\
& Nitric acid $(13.7 \mathrm{~g})$ & Yttrium $(0.1 \mathrm{~g})$ & Citric acid $(2.9 \mathrm{~g})$ \\
Raw-materials & Yttrium $(0.2 \mathrm{~g})$ & Ethylene glycol $(0.2 \mathrm{~g})$ & Strontium $(1.1 \mathrm{~g})$ \\
& Zirconium $(0.9 \mathrm{~g})$ & Isopropanol $(1.5 \mathrm{~g})$ & Ytterbium $(1.1 \mathrm{~g})$ \\
& Distilled water $(21.5 \mathrm{~g})$ & & Zirconium $(1.1 \mathrm{~g})$ \\
\hline Electrical equipment & Running time $(\mathrm{h})$ & Running time $(\mathrm{h})$ & Running time $(\mathrm{h})$ \\
\hline Drying oven & $48(57.6 \mathrm{kWh})$ & $2(3.8 \mathrm{kWh})$ & $24(28.8 \mathrm{kWh})$ \\
\hline Electric furnace & $5(25 \mathrm{kWh})$ & $8(40 \mathrm{kWh})$ & $9(945 \mathrm{kWh})$ \\
\hline \multirow{2}{*}{ Emissions to water } & Ammonia $(3.6 \mathrm{~g})$ & Ethylene glycol $(0.2 \mathrm{~g})$ & Ammonia $(0.6 \mathrm{~g})$ \\
\hline Emissions to air & Nitric acid $(13.7 \mathrm{~g})$ & \multicolumn{3}{c}{ Isopropanol $(1.5 \mathrm{~g})$} \\
\hline
\end{tabular}


Figure 1. Flow charts of experimental procedures

of (a) BZY20 $\quad\left(\mathrm{BaZr}_{0.8} \mathrm{Y}_{0.2} \mathrm{O}_{3-\delta}\right)$;

(b) $\quad$ BCY10 $\quad\left(\mathrm{BaCe}_{0.9} \mathrm{Y}_{0.1} \mathrm{O}_{2.95}\right)$;

(c) $\operatorname{SCZY}\left(\operatorname{Sr}\left(\mathrm{Ce}_{1-\mathrm{x}} \mathrm{Zr}_{\mathrm{x}}\right)_{0.95} \mathrm{Yb}_{0.05} \mathrm{O}_{3-\delta}\right)$.

(a)

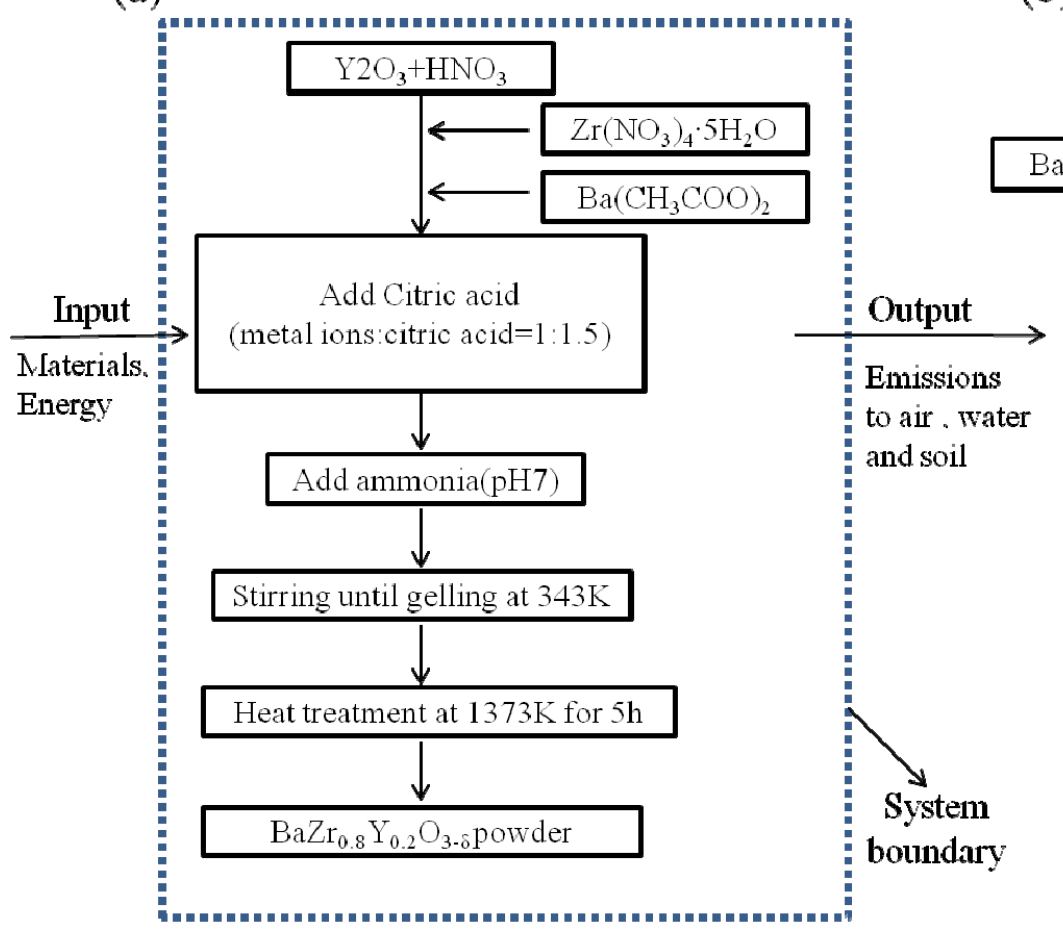

(b)

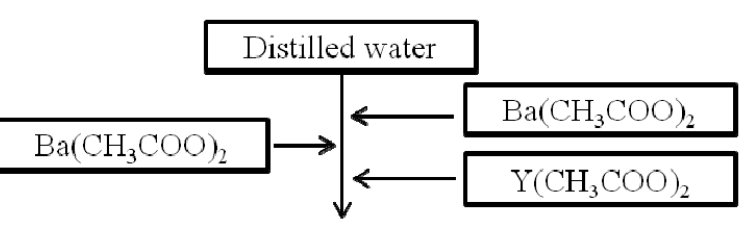

Stirring until gelling at $343 \mathrm{~K}$

Ethylene glycol+ Isopropanol(10:90)

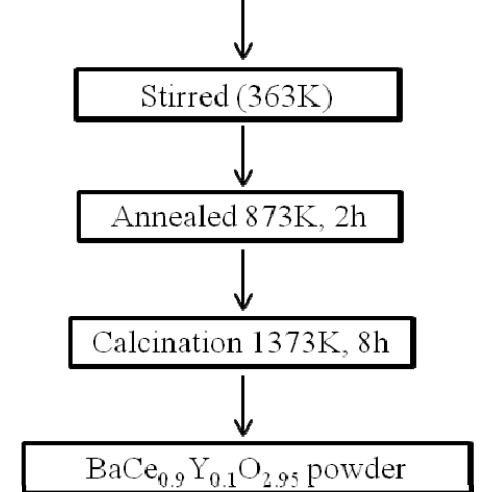

(c)

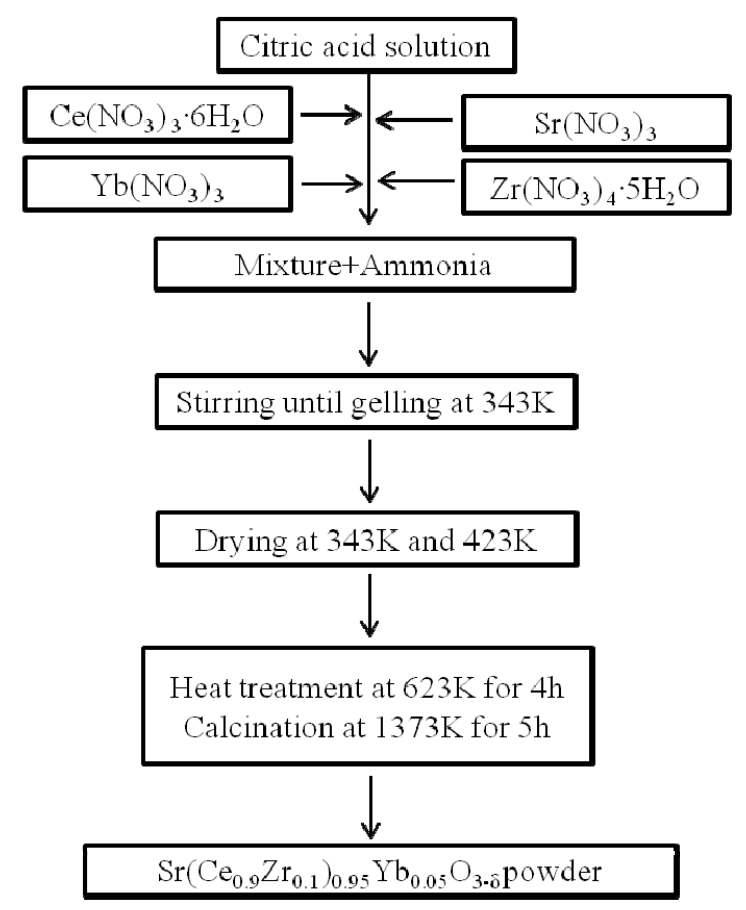


When an exact dataset could not be used, we chose an appropriate proxy $[11,12]$. It should be noted that, for the heat treatment and calcination process, the three s samples had different energy requirements. The first stage of sol preparation involved mixing the chemicals together. Then this mixture was stirred until it turned into a gel.

\section{Results}

Classification, characterization and normalization stages were undertaken in this study. Results of the characterization calculated per $1 \mathrm{~g}$ of synthesized BZY20, BCY10 and SCZY are shown in Table 2.

The normalization is based on the national inventory of world impact. The normalized results are displayed in Figure 2. BZY20 has the highest impacts, followed by SZCY, and BCY10. The graphs show that the normalized impact is similar for all three samples in terms of marine aquatic ecotoxicity potential (MAETP) made up the largest part among the tem environmental impact categories followed by fresh-water aquatic ecotoxicity potential (FAETP) and Human Toxicity Potential (HTP). The major environmental impact of these materials is due to the use of electricity (the NL electricity mix). The majority of the energy consumption occurs during the annealing and calcinations steps. Among the three powders, the impacts of BCY10 are lower compared to the others, because the electricity needed is lower than that of the other processes $(157.68 \mathrm{MJ})$. Thus, temperature and holding time are potential areas for reducing the environmental impact.

Figure 3 shows ADP (abiotic resource depletion), AP (aciedification potential), EP (eutrophication potential), HTP (Human Toxicity Potential), and POCP (Photochem. Ozone Creation Potential) values for the produced proton conducting ceramics when the impact of electricity is not considered for a material life cycle assessment. In the case of BZY20, the highest impact is AP, followed by EP, HTP and ADP. In Table 3, we show the contributors to AP are nitric acid (51\%), which is one of the stronger acidic solutions, and ammonia (49\%). Thus, it has negative impacts on the environment and experimenters. Ammonia is used in a neutralization reaction, and affects the EP and HTP impact. The contributors to the ADP impact are barium, zirconium and yttrium rare metals.

In the case of SCZY, the highest impact is ADP, followed by AP, EP and HTP impacts. Like BZY20, SCZY also involves nitric acid and ammonia. However, with BCY10, acidic and basic solutions are not used, which mainly explains its low impact. BCY10 impacts two category indicators (ADP and POCP). The contributors to PCOP are isopropanol and ethylene glycol. The results indicate that the choice of neutralization reaction material has a significant impact.

These results can be useful in process decisions by providing a quantifiable basis for potential improvements in environmental performance of sol-gel processes. In particular, reducing the use of acidic and basic solutions would be favorable improvements for the environment and humans. In addition, considering the industrial scale, one of the advantages of Sol-gel process is relatively uncomplicated to transfer at an industrial scale [13]. Thus, if this method is applied to a large scale, the potential effect is not large. Instead, if the process is improved efficiently, the energy consumption for stage of mass production could be expected to decrease. 
Table 2. Characterized impacts of the production of BZY20, BCY10 and SCZY.

\begin{tabular}{|c|c|c|c|c|}
\hline \multirow{2}{*}{ Impacts category } & \multirow{2}{*}{ Unit } & \multicolumn{3}{|c|}{ Life cycle environmental impacts } \\
\hline & & BZY20 & BCY10 & SCZY \\
\hline $\begin{array}{l}\text { Abiotic depletion } \\
\text { (ADP) }\end{array}$ & $\mathrm{kg} \mathrm{Sb}-\mathrm{Eq}$ & $1.58 \times 10^{-7}$ & $8.10 \times 10^{-8}$ & $1.31 \times 10^{-7}$ \\
\hline $\begin{array}{l}\text { Acidification potential } \\
\text { (AP) }\end{array}$ & $\mathrm{kg} \mathrm{SO}_{2}-\mathrm{Eq}$ & $1.56 \times 10^{-2}$ & $2.08 \times 10^{-3}$ & $3.50 \times 10^{-3}$ \\
\hline $\begin{array}{l}\text { Eutrophication potential } \\
\text { (EP) }\end{array}$ & $\mathrm{kg} \mathrm{PO}_{4}^{-3}-\mathrm{Eq}$ & $5.43 \times 10^{-3}$ & $1.48 \times 10^{-3}$ & $2.50 \times 10^{-3}$ \\
\hline $\begin{array}{l}\text { Global warming potential } \\
\text { (GWP } 100 \text { years) }\end{array}$ & $\mathrm{kg} \mathrm{CO}_{2}-\mathrm{Eq}$ & $2.83 \times 10^{0}$ & $1.50 \times 10^{0}$ & $2.53 \times 10^{0}$ \\
\hline $\begin{array}{l}\text { Fresh-water aquatic ecotoxicity potential } \\
\text { (FAETP) }\end{array}$ & $\mathrm{kg}$ DCB-Eq & $3.82 \times 10^{-1}$ & $2.02 \times 10^{-1}$ & $3.41 \times 10^{-1}$ \\
\hline $\begin{array}{c}\text { Marine aquatic ecotoxicity potential } \\
\text { (MAETP) }\end{array}$ & $\mathrm{kg}$ DCB-Eq & $1.31 \times 10^{3}$ & $6.95 \times 10^{2}$ & $1.17 \times 10^{3}$ \\
\hline $\begin{array}{c}\text { Terrestrial ecotoxicity potential } \\
\text { (TETP) }\end{array}$ & kg DCB-Eq & $2.20 \times 10^{-3}$ & $1.17 \times 10^{-3}$ & $1.97 \times 10^{-3}$ \\
\hline $\begin{array}{c}\text { Human toxicity potential } \\
\text { (HTP) }\end{array}$ & kg DCB-Eq & $3.20 \times 10^{-1}$ & $1.70 \times 10^{-1}$ & $2.86 \times 10^{-1}$ \\
\hline $\begin{array}{c}\text { Ozone layer depletion potential } \\
\text { (ODP) }\end{array}$ & kg R11-Eq & $1.06 \times 10^{-7}$ & $5.65 \times 10^{-8}$ & $9.50 \times 10^{-8}$ \\
\hline $\begin{array}{l}\text { Photochem. ozone creation potential } \\
\text { (POCP) }\end{array}$ & $\mathrm{kg} \mathrm{C}_{2} \mathrm{H}_{4}-\mathrm{Eq}$ & $3.57 \times 10^{-4}$ & $5.29 \times 10^{-4}$ & $3.19 \times 10^{-4}$ \\
\hline
\end{tabular}

Figure 2. Normalized impacts of BZY20, BZY10 and SCZY the according to CML 2001.

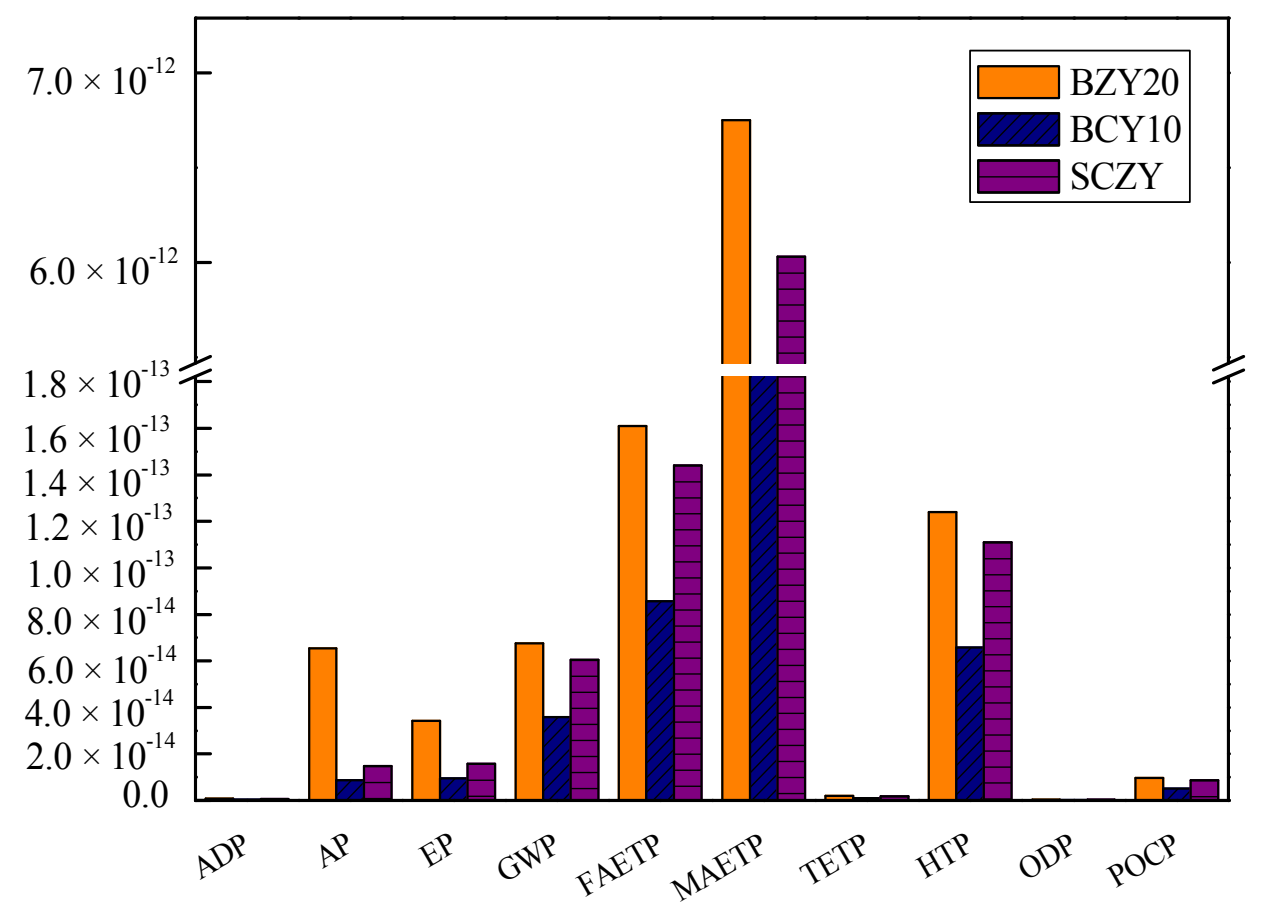


Figure 3. Normalized impacts of BZY20, BZY10 and SCZY (without electricity).

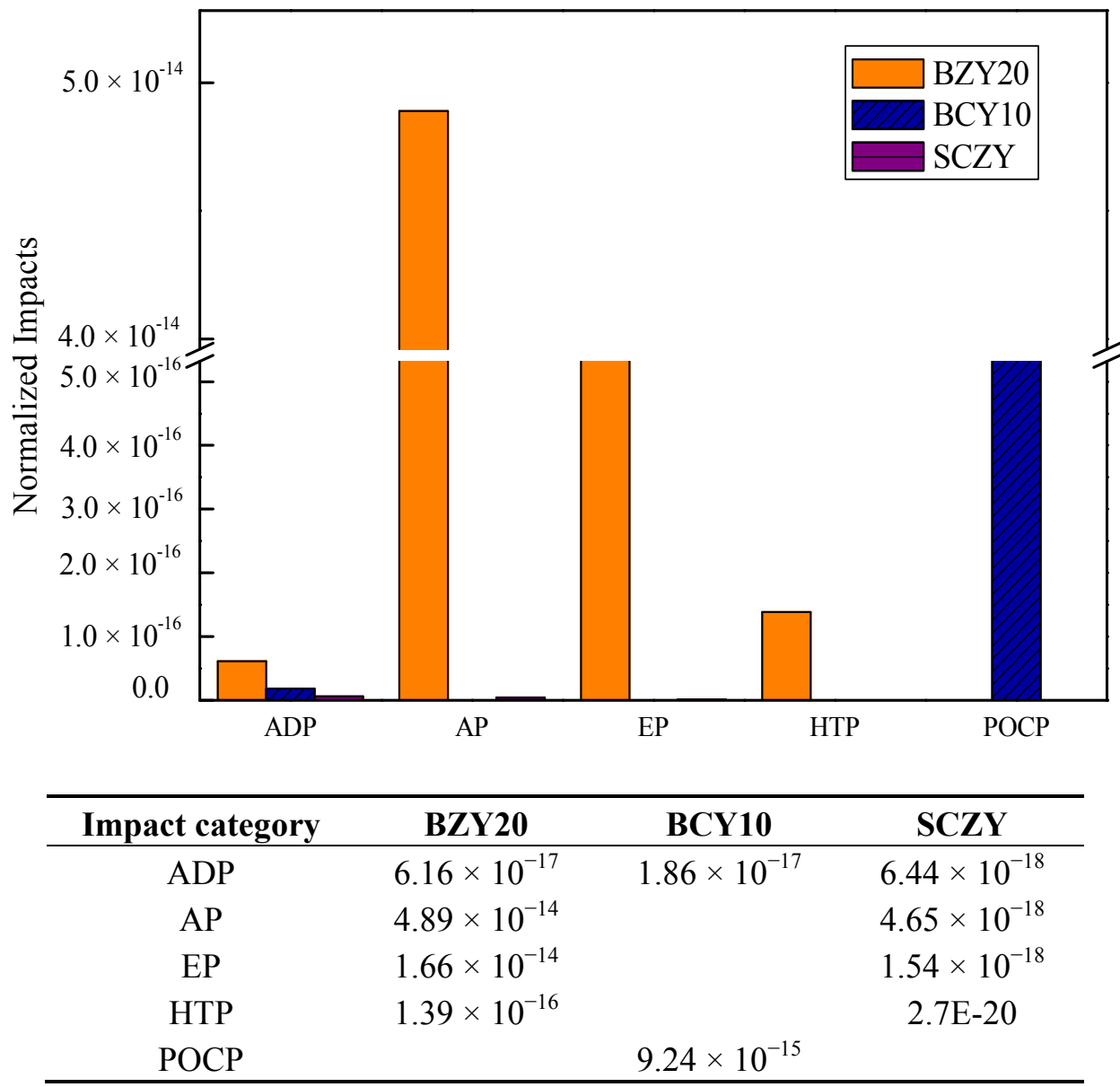

Table 3. Contribution to Environmental Impacts.

\begin{tabular}{cccc}
\hline Impact category & BZY20 & BCY10 & SCZY \\
\hline \multirow{2}{*}{ ADP } & Barium (60\%) & Barium (99\%) & Strontium (56\%) \\
& $\begin{array}{c}\text { Zirconium (39\%) } \\
\text { Yttrium (1\%) }\end{array}$ & Yttrium (1\%) & Zirconium (44\%) \\
\hline \multirow{2}{*}{ AP } & $\begin{array}{c}\text { Nitric acid (51\%) } \\
\text { Ammonia (49\%) }\end{array}$ & - & Ammonia (100\%) \\
\hline \multirow{2}{*}{ EP } & $\begin{array}{c}\text { Nitric acid (52\%) } \\
\text { Ammonia (47\%) }\end{array}$ & - & Ammonia (100\%) \\
\hline HTP & Ammonia (100\%) & - & Ammonia (100\%) \\
\hline \multirow{2}{*}{ POCP } & - & $\begin{array}{c}\text { Isopropanol (82\%) } \\
\text { Ethylene glycol (18\%) }\end{array}$ & - \\
\hline
\end{tabular}

\section{Conclusions}

In this paper, the environmental impacts of the synthesis of proton conducting (BZY20, BCY10 and SCZY) materials by the sol-gel method were quantified and described using a life cycle analysis. Several conclusions are drawn from this study.

(1) BZY20 was found to have the highest impacts, followed by SZCY, and BCY10. The normalized results for BZY20 showed marine aquatic ecotoxicity potential (MAETP) made up the largest part 
followed by fresh-water aquatic ecotoxicity potential (FAETP) and Human Toxicity Potential (HTP). Both BCY10, SCZY showed similar results. The level of energy consumption of the annealing and calcinations steps produced the largest contribution. Thus, temperature and holding time are potentially key targets for reducing the environmental impact.

(2) After excluding the impact of electricity, a material life cycle assessment was conducted. As in the previous results, BZY20 was found to have the highest impacts, followed by SZCY, and BCY10. This is because the use of acidic and basic solutions affected AP (acidification potential) and EP (eutrophication potential). The use of materials such as zirconium and yttrium affected the ADP (abiotic resource depletion) impact. The results indicate that the choice of material (rare metal and solution) has a significant impact. In addition, if the process is improved efficiently, the energy consumption for stage of mass production could be expected to decrease.

\section{Acknowledgments}

This work was supported by a National Research Foundation of Korea Grant funded by the Korean Government (MEST) (NRF-2009-0093168) and National R\&D Program through the National Research Foundation of Korea (NRF) funded by the Ministry of Science, ITC \& Future Planning (NRF-2013M1A7A1A02043993)

\section{Author Contributions}

Soo-Sun Lee and Tae-Whan Hong conceived and designed the experiments and life cycle assessment; Soo-Sun Lee performed the experiments and wrote the paper; Tae-Whan Hong advised Soo-Sun Lee on experimental results and edited the paper.

\section{References}

1. Guan, J.; Dorris, S.E.; Balachandran, U.; Liu, M. Transport properties of $\mathrm{BaCe}_{0.95} \mathrm{Y}_{0.05} \mathrm{O}_{3-\alpha}$ mixed conductors for hydrogen separation. Solid State Ionics. 1997, 100, 45-52.

2. Lee, K.C.; Choi, M.B.; Lim, D.K.; Singh, B.; Song, S.J. Effect of humidification on the performance of intermediate-temperature proton conducting ceramic fuel cells with ceramic composite cathodes. J. Power Sources 2013, 232, 224-233.

3. Suksamai, W.; Metcalfe, I.S. Measurement of proton and oxide ion fluxes in a working Y-doped $\mathrm{BaCeO}_{3}$ SOFC. Solid State Ionics 2007, 178, 627-634.

4. Iwata, N.Y.; Lee, G.H.; Tsunakawa, S.; Tokuoka, Y.; Kawashima, N. Preparation of diopside with apatite-forming ability by sol-gel process using metal alkoxide and metal salts. Colloids Surf. B 2004, 33, 1-6.

5. Cervera, R.B.; Oyama, Y.; Yamaguchi, S. Low temperature synthesis of nanocrystalline proton conducting $\mathrm{BaZr}_{0.8} \mathrm{Y}_{0.2} \mathrm{O}_{3-\delta}$ by sol-gel method. Solid State Ionics 2007, 178, 569-574.

6. Princivalle, A.; Martin, G.; Viazzi, C.; Guizard, C.; Grunbaum, N.; Dessemond, L. Sintering and conductivity of $\mathrm{BaCe}_{0.9} \mathrm{Y}_{0.1} \mathrm{O}_{2.95}$ synthesized by the sol-gel method. J. Power Sources 2011, 196, 9238-9245. 
7. Zhang, J.; Wen, Z.; Han, J.; Wu, J.; Huang, S.; Zhu, X. Synthesis and characterization of proton conducting $\operatorname{Sr}\left(\mathrm{Ce}_{1-\mathrm{x}} \mathrm{Zr}_{\mathrm{x}}\right)_{0.95} \mathrm{Yb}_{0.05} \mathrm{O}_{3-\delta}$ by the citrate method. J. Alloys Compd. 2007, 440, 270-275.

8. Audenaert, A.; de Cleyn, S.H.; Buyle, M. LCA of low-energy flats using the Eco-indicator 99 method: Impact of insulation materials. Energ. Build. 2012, 47, 68-73.

9. Rolf, F.; Gerald, R. The ecoinvent database system: A comprehensive web-based LCA database. J. Clean. Prod. 2005, 13, 1337-1343.

10. Iritani, D.R.; Silva, D.A.L.; Saavedra, Y.M.B.; Grael, R.F.F.; Ometto, A.R. Sustainable Strategies Analysis Through Life Cycle Assessment: A case study in a furniture industry. J. Clean. Prod. 2014, doi:10.1016/j.jclepro.2014.05.029.

11. Provo, J.; Fava, J.; Baer, S. Life Cycle Assessment and the chemical engineer: A marriage of convenienve. Chem. Eng. 2013, 2, 278-281.

12. Burgess, A.A.; Brennan, D.J. Application of life cycle assessment to chemical processes. Chem. Eng. Sci. 2001, 56, 2589-2604.

13. Viazzi, C.; Deboni, A.; Ferreira, J.Z.; Bonino, J.P.; Ansart, F. Synthesis of Yttria Stabilized Zirconia by sol-gel route: Influence of experimental parameters and large scale production. Solid State Sci. 2006, 8, 1023-1028.

(C) 2014 by the authors; licensee MDPI, Basel, Switzerland. This article is an open access article distributed under the terms and conditions of the Creative Commons Attribution license (http://creativecommons.org/licenses/by/3.0/). 